\title{
ANALISIS SGPT-SGOT EKSTRAK ETANOL DAGING BUAH PARE (Momordica Charantia L.) PADA TIKUS JANTAN PUTIH GALUR WISTAR
}

\section{ANALYSIS OF SGPT-SGOT OF ETHANOL EXTRACT OF FRUIT PARE (Momordica Charantia L.) TO MALE WISTAR RATS}

\author{
Dwi Ari Nugrahani, Vivi Sofia \\ Fakultas Farmasi Universitas Ahmad Dahlan Yogyakarta \\ Jl. Prof. Dr. Soepomo, Yogyakarta, Telp. (0274) 379418
}

\section{Abstrak}

Obat tradisional di Indonesia yang merupakan warisan budaya dan telah menjadi bagian integral dari kehidupan bangsa Indonesia, diinginkan untuk dapat dipakai dalam sistem pelayanan kesehatan formal. Sebagaimana syarat peredaran obat pada umumnya, obat tradisional seharusnya memenuhi persyaratan kualitas, aman, dan berkhasiat. Penelitian ini bertujuan untuk menganalisis kadar SGPT-SGOT dari pemberian suspensi ekstrak etanol buah pare (Momordica charantia L.) yang diberikan secara peroral. Penelitian dilakukan menggunakan tikus jantan putih galur Wistar berjumlah 36 ekor, dibagi menjadi 6 kelompok. Setiap kelompok terdiri dari 6 ekor tikus jantan putih. Kelompok I (kontrol) diberi larutan CMC 0,5\% 2,5 ml/200 g $B B$. Kelompok II diberi sediaan suspensi ekstrak etanol buah pare dosis $0,5 \mathrm{~g} / \mathrm{kg} \mathrm{BB}$, kemudian berturut-turut kelompok III dengan dosis sediaan uji $1 \mathrm{~g} / \mathrm{kg} \mathrm{BB}$, kelompok $\mathrm{IV}$ diberi sediaan uji dosis $2 \mathrm{~g} / \mathrm{kg} \mathrm{BB}$, kelompok $V$ diberi sediaan uji dosis $4 \mathrm{~g} / \mathrm{kg} B B$, dan kelompok VI diberi sediaan uji dosis tertinggi $8 \mathrm{~g} / \mathrm{kg}$ BB. Hasil uji ketoksikan akut pada tikus putih jantan galur Wistar menunjukkan bahwa dari pemberian peroral sediaan suspensi ekstrak etanol buah pare (Momordica charantia L.) dosis tunggal pada tikus jantan putih galur Wistar mulai dari dosis $0,5 \mathrm{~g} / \mathrm{kg} \mathrm{BB}$ sampai dengan dosis $8 \mathrm{~g} / \mathrm{kg} \mathrm{BB}$ tidak berpengaruh signifikan terhadap nilai SGPT-SGOT.

Kata Kunci : buah pare, toksisitas, kimia darah 


\section{Abstract}

The traditional medicine in Indonesia which is the cultural heritage and has become an integral part of the life of the nation Indonesia, want to be employed in the formal health care system. As the circulation of drugs in general terms, traditional medicine should fulfill the requirements of quality, safe, and efficacious. This study aims to analyze the levels of SGPT, SGOT of suspension of the ethanol extract of bitter melon fruit (Momordica charantia L.) by orally. The study was conducted using a white male Wistar rats amounted to 36 animals, divided into 6 groups. Each group consisted of 6 male white rats. Group I (control) were given $0.5 \%$ CMC solution of $2.5 \mathrm{ml} / 200 \mathrm{~g}$ $B W$. Group II was given a suspension dosage doses of bitter melon fruit extract ethanol $0.5 \mathrm{~g} / \mathrm{kg}$, then consecutive group III with the test preparation doses of $1 \mathrm{~g} / \mathrm{kg}$, the test preparation group $\mathrm{IV}$ were given a dose of $2 \mathrm{~g} / \mathrm{kg}$, group $V$ was given dosage test dose of $4 \mathrm{~g} / \mathrm{kg}$, and group VI were given the highest dose of the test preparation $8 \mathrm{~g} / \mathrm{kg}$. The results of acute toxicity tests on white male Wistar rats showed that administration of ethanol extract of peroral dosage suspension pare (Momordica charantia L.) single dose on white male Wistar rats from the dose of $0.5 \mathrm{~g} / \mathrm{kg}$ until a dose of $8 \mathrm{~g} / \mathrm{kg}$ did not significantly influence the value of SGPT, SGOT.

Keywords: $\quad$ bitter melon fruit, toxicity, blood chemistry

\section{PENDAHULUAN}

Hati mempunyai peranan pada hampir setiap fungsi metabolik tubuh, khususnya bertanggung jawab atas lebih dari 500 aktivitas berbeda (Wilson, 1994). Pada proses metabolisme, sejumlah besar senyawa xenobiotik dilaporkan berpotensi untuk menimbulkan kerusakan hati (hepatotoksik). Radikal bebas yang dihasilkan dari proses metabolisme suatu xenobiotik dapat menginduksi lesi dari hati dan bereaksi dengan penyusun seluler hati, seperti protein, lipid, RNA dan DNA. Kerusakan pada hati akan ditunjukkan oleh aktivitas enzim seluler yang semakin meningkat. Beberapa enzim yang meningkat pada saat terjadi nekrosis hepatoseluler, misalnya Serum Glutamat
Piruvate Transaminase (SGPT), Serum Glutamate Oxaloacetate Transaminase (SGOT), Sorbitol Dehydrogenase (SDH) (Suckow dkk, 2006).

Obat tradisional lebih mudah diterima oleh masyarakat karena selain telah akrab dengan masyarakat, obat ini lebih murah dan mudah didapat. Dalam pengobatan tradisional, tanaman pare (Momordica charantia L.) memberikan andil yang cukup besar bagi masyarakat. Pare merupakan salah satu tanaman yang digunakan sebagai obat tradisional karena mempunyai beberapa khasiat, diantaranya perasan daunnya dapat dipakai sebagai obat cacing, obat muntah. Buahnya dapat digunakan untuk obat encok, tonikum, membersihkan darah dan obat penyakit gula (Dharma, 1985). 
Disamping itu, pare juga berkhasiat sebagai penurun panas, penyegar badan, pelancar pencernaan makanan, obat kanker dan peluruh haid (Wijayakusuma dkk, 1995).

Mengingat obat tradisional adalah sarana kesehatan dan menyangkut keselamatan masyarakat, mau tidak mau obat tradisional harus mendapat perhatian tersendiri agar tidak terjadi penyimpangan dan akibat yang tidak diinginkan. Sebagaimana syarat peredaran obat pada umumnya, obat tradisional seharusnya memenuhi persyaratan aman, manjur, dan dapat diterima oleh pasien. Biasanya penggunaan obat tradisional untuk pengobatan di dalam masyarakat, dosis atau takaran yang digunakan tidak ada standar resmi yang menyatakan dosis lazim dan dosis maksimum sehingga memungkinkan terjadinya efek samping akibat penggunaan obat tradisional yang melebihi batas amannya.

Masalah yang timbul adalah belum adanya informasi yang menyampaikan tentang batas aman dalam penggunaan obat tradisional tersebut, seperti pengaruhnya terhadap nilai SGPT-SGOTnya.

Dengan dasar pemikiran tersebut dilakukan penelitian yang diharapkan dapat memberikan informasi kepada masyarakat tentang analisis nilai SGPT-SGOT dari ekstrak daging buah pare sebagai salah satu obat tradisional yang juga harus memenuhi persyaratan aman dan manjur, sehingga dapat lebih diterima dalam pelayanan kesehatan formal dan memungkinkan potensi obat tradisional untuk dikembangkan sampai tingkat pengobatan modern.

\section{METODE PENELITIAN}

\section{Bahan}

Hewan uji yang digunakan adalah tikus jantan putih galur Wistar, berat seragam, berumur 3-4 bulan yang diperoleh dari Universitas Sanata Dharma, bahan uji adalah ekstrak etanol daging buah pare (M. Charantia L.). Buah pare diperoleh dari daerah Pakem, Kaliurang, Yogyakarta, CMC Na 0,5\%, aquades, etanol $70 \%$.

\begin{abstract}
Alat
Alat gelas seperti corong Buchner, injeksi oral, timbangan analitik dan spektrofotometer.
\end{abstract}

\section{Jalannya Penelitian}

1. Uji Pengaruh Ekstrak Daging Buah Pare Terhadap Kadar SGPT dan SGOT Serum Tikus

Hewan uji sebanyak 30 ekor tikus dibagi menjadi 6 kelompok perlakuan. Setiap kelompok terdiri dari 6 ekor tikus.

Pengelompokan dan Perlakuan Hewan Uji

Kelompok : kelompok kontrol, diberi larutan $\mathrm{CMC} \mathrm{Na}$ $0,5 \% 2,5 \mathrm{ml} / 200 \mathrm{~g} \mathrm{BB}$

Kelompok II : kelompok yang diberi suspensi sediaan dengan dosis $0,5 \mathrm{~g} / \mathrm{kg}$ BB

Kelompok III : diberi suspensi sediaan uji dengan dosis $1 \mathrm{~g} / \mathrm{kg}$ BB

Kelompok IV : diberi suspensi sediaan uji dengan dosis $2 \mathrm{~g} / \mathrm{kg}$ BB 
Kelompok V : diberi suspensi sediaan dengan dosis $4 \mathrm{~g} / \mathrm{kg} \mathrm{BB}$

Kelompok VI : kelompok yang diberi suspensi sediaan dengan dosis $8 \mathrm{~g} / \mathrm{kg} \mathrm{BB}$

\section{Pembuatan Ekstrak Etanol Daging} Buah Pare

Proses pembuatan ekstraksi etanol daging buah pare dilakukan dengan cara meserasi menggunakan penyari etanol $70 \%$ agar kandungan zat aktif lebih banyak yang tersari.

Serbuk daging buah pare dimaserasi dalam larutan etanol $70 \%$ dan diaduk selama 3 jam dengan mesin pengaduk (stirer), lalu didiamkan selama satu hari atau 24 jam. Campuran tersebut kemudian disaring menggunakan corong Buchner dan didapat filtrat I, sedangkan bahan sisa dimaserasi kembali dalam etanol $70 \%$ yang baru, dan dilakukan proses seperti langkah sebelumnya hingga didapatkan filtrat II dan begitu seterusnya. Penggunaan larutan penyari yang baru terhadap bahan sisa ini dihentikan apabila filtrat yang didapat sudah jernih. Filtrat-filtrat yang diperoleh kemudian dicampur dan diuapkan menggunakan rota evaporator yang dibantu dengan pompa vakum hingga etanolnya tinggal sedikit dan ekstrak bisa dituang. Selanjutnya dipekatkan kembali di atas penangas air dengan bantuan kipas angin sampai kental sesuai dengan yang diinginkan, lalu ekstrak kental tersebut disimpan dalam almari pendingin.

3. Pengambilan serum dan Pembacaan Aktivitas SGPT dan SGOT

Darah diambil dari sinus orbitalis mata dengan hematokrit sebanyak $1 \mathrm{cc}$ dan ditampung dalam Eppendorf, kemudian sempel darah disentrifugasi untuk mendapatkan serumnya. Setelah itu, dibaca aktivitas SGOT dan SGPT dengan reagen Kit menggunakan alat Mikrolab 300 di LPPT UGM, dengan metode spektrofotometri dengan menggunakan panjang gelombang $340 \mathrm{~nm}$.

\section{Analisis Statistika}

Dari data hasil penelitian dilakukan analisis statistika dengan menggunakan Anova dan dilanjutkan dengan Uji LSD.

Tabel I. Aktivitas SGPT Hewan Uji Akibat Perlakuan Ekstrak Etanol Daging Buah Pare

\begin{tabular}{|lccc|}
\hline & \multicolumn{3}{c|}{ SGPT (Mean \pm SD (U/L) Hari ke-) } \\
\cline { 2 - 4 } & $\mathbf{1}$ & $\mathbf{7}$ & $\mathbf{1 4}$ \\
\hline Kelompok & $79,40 \pm 13,29$ & $47,76 \pm 10,72$ & $71,1 \pm 10,31$ \\
Dosis $0,5 \mathrm{mg} / \mathrm{kg} \mathrm{BB}$ & $81,50 \pm 2,25$ & $75,4 \pm 8,01$ & $67,06 \pm 6,24$ \\
Dosis $1 \mathrm{mg} / \mathrm{kg} \mathrm{BB}$ & $86,90 \pm 1,00$ & $63,94 \pm 6,08$ & $62,28 \pm 6,14$ \\
Dosis 2 mg/kg BB & $72,53 \pm 6,70$ & $66,1 \pm 6,08$ & $66,92 \pm 7,41$ \\
Dosis 4 mg/kg BB & $62,3 \pm 6,92$ & $55,43 \pm 5,47$ & $70,1 \pm 6,39$ \\
Dosis 8 g/kg BB & $77,16 \pm 6,18$ & $54,575 \pm 2,77$ & $56,73 \pm 9,97$ \\
\hline
\end{tabular}


Tabel II. Hasil Uji Statistik Perbandingan Data Aktivitas SGPT antara Kelompok Kontrol dengan Kelompok Dosis Hari ke-0, 7 dan 14

\begin{tabular}{|ccccc|}
\hline \multirow{2}{*}{ Waktu } & \multirow{2}{*}{ Distribusi Data } & Uji Homogenitas & \multicolumn{2}{c|}{ Parametrik } \\
\cline { 4 - 5 } & & & ANOVA & Post Hoc \\
\hline Hari ke-0 & $\mathrm{TN}$ & $\mathrm{DH}$ & $\mathrm{TBB}$ & TBB \\
Hari ke-7 & $\mathrm{TN}$ & $\mathrm{DH}$ & $\mathrm{TBB}$ & TBB \\
Hari ke-14 & $\mathrm{TN}$ & $\mathrm{DH}$ & $\mathrm{TBB}$ & TBB \\
\hline
\end{tabular}

Keterangan :

$\begin{array}{ll}\text { TN } & \text { : terdistribusi normal } \\ \text { DH } & : \text { data homogen } \\ \text { TBB } & \text { : tidak berbeda bermakna }\end{array}$

\section{HASIL DAN PEMBAHASAN}

Gambaran aktivitas SGPT pada hewan uji akibat pemberian sediaan uji dapat dilihat pada Tabel I, sedangkan pada Tabel II dapat dilihat bahwa kadar SGPT pada kelompok kontrol secara statistika memiliki perbedaan yang tidak berbeda signifikan dibandingkan dengan kelompok perlakuan yang lain, yang telah diberi sediaan uji pada masingmasing kelompok dosis $0,5 \mathrm{~g} / \mathrm{kg} \mathrm{BB}, 1$ $\mathrm{g} / \mathrm{kg} \mathrm{BB}, 2 \mathrm{~g} / \mathrm{kg} \mathrm{BB}, 4 \mathrm{~g} / \mathrm{kg} \mathrm{BB}$, dan 8 $\mathrm{g} / \mathrm{kg} \mathrm{BB}$ baik pada hari ke-1, hari ke-7 dan hari ke-14. Hal tersebut menunjukan bahwa pemberian sediaan uji pada masing-masing kelompok dosis tidak menimbulkan kerusakan hati yang ditandai dengan terjadinya peningkatan kadar SGPT. Sehingga, pengaruh ekstrak etanol daging buah pare sampai dengan pemberian $8 \mathrm{~g} / \mathrm{kg}$ BB tidak berpengaruh terhadap hewan uji. Hal tersebut menunjukkan bahwa bahan uji tidak toksik dan tidak mempengaruhi organ tubuh, sehingga tidak mempengaruhi metabolisme tubuh.

Tabel III. Gambaran SGOT Hewan Uji Akibat Perlakuan Ekstrak Etanol Daging Buah Pare

\begin{tabular}{|lccc|}
\hline & \multicolumn{3}{c|}{ SGOT (Mean \pm SD (U/L) Hari ke-) } \\
\cline { 2 - 4 } Kelompok & $\mathbf{1}$ & $\mathbf{7}$ & $\mathbf{1 4}$ \\
\hline Kontrol & $141,95 \pm 13,22$ & $99,9 \pm 15,51$ & $126,07 \pm 15,64$ \\
Dosis $0,5 \mathrm{mg} / \mathrm{kg} \mathrm{BB}$ & $137,1 \pm 9,48$ & $93,1 \pm 9,25$ & $158,28 \pm 9,07$ \\
Dosis $1 \mathrm{mg} / \mathrm{kg} \mathrm{BB}$ & $138,3 \pm 7,78$ & $109,45 \pm 6,93$ & $140,98 \pm 6,88$ \\
Dosis $2 \mathrm{mg} / \mathrm{kg} \mathrm{BB}$ & $158,2 \pm 1,13$ & $149,7 \pm 5,73$ & $133,86 \pm 5,62$ \\
Dosis $4 \mathrm{mg} / \mathrm{kg} \mathrm{BB}$ & $140,43 \pm 11,41$ & $100,35 \pm 10,08$ & $138,44 \pm 1278$ \\
Dosis $8 \mathrm{~g} / \mathrm{kg} \mathrm{BB}$ & $192,3 \pm 8,34$ & $142,33 \pm 10,09$ & $100,37 \pm 3,12$ \\
\hline
\end{tabular}


Hasil uji statistik kadar SGOT

hewan uji dapat dilihat pada Tabel IV.

Tabel IV. Hasil Uji Statistik Perbandingan Data Aktivitas SGOT antara Kelompok Kontrol dengan Kelompok Dosis Hari ke-0, 7 dan 14

\begin{tabular}{|ccccc|}
\hline \multirow{2}{*}{ Waktu } & \multirow{2}{*}{ Distribusi Data } & Uji Homogenitas & \multicolumn{2}{c|}{ Parametrik } \\
\cline { 4 - 5 } & & & ANOVA & Post Hoc \\
\hline Hari ke-0 & TN & DH & TBB & TBB \\
Hari ke-7 & TN & DH & TBB & TBB \\
Hari ke-14 & TN & DH & TBB & TBB \\
\hline
\end{tabular}

Keterangan :

TN : terdistribusi normal

DH : data homogen

TBB : tidak berbeda bermakna

Pada Tabel IV dapat dilihat bahwa aktivitas SGPT pada kelompok kontrol secara statistika memiliki perbedaan yang tidak berbeda signifikan dibandingkan dengan kelompok perlakuan yang lain, yang telah diberi sediaan uji pada masing-masing kelompok dosis 0,5 $\mathrm{g} / \mathrm{kg} \mathrm{BB}, 1 \mathrm{~g} / \mathrm{kg} \mathrm{BB}, 2 \mathrm{~g} / \mathrm{kg} \mathrm{BB}, 4 \mathrm{~g} / \mathrm{kg}$ $\mathrm{BB}$, dan $8 \mathrm{~g} / \mathrm{kg}$ BB baik pada hari ke-1, hari ke-7 dan hari ke-14. Hal tersebut menunjukan bahwa pemberian sediaan uji pada masing-masing kelompok dosis tidak menimbulkan kerusakan hati yang ditandai dengan terjadinya peningkatan kadar SGPT. Sehingga, pengaruh ekstrak etanol daging buah pare sampai dengan pemberian $8 \mathrm{~g} / \mathrm{kg}$ BB tidak berpengaruh terhadap hewan uji. Hal tersebut menunjukkan bahwa bahan uji tidak toksik dan tidak mempengaruhi organ tubuh, sehingga tidak mempengaruhi metabolisme tubuh.

\section{KESIMPULAN}

Berdasarkan Hasil Penelitian bahwa ekstrak etanol daging buah pare (Momordica charantia L.) pada kisaran dosis $0,5 \mathrm{~g} / \mathrm{kg} \mathrm{BB}, 1 \mathrm{~g} / \mathrm{kg} \mathrm{BB}, 2 \mathrm{~g} / \mathrm{kg} \mathrm{BB}$, $4 \mathrm{~g} / \mathrm{kg} \mathrm{BB}$, dan $8 \mathrm{~g} / \mathrm{kg}$ BB tidak berpengaruh signifikan terhadap nilai SGPT-SGOT.

\section{DAFTAR PUSTAKA}

Dharma, A.P., 1985, Tanaman Obat Tradisional Indonesia, Cetakan I, 235-236, P.N. Balai Pustaka, Jakarta

Loomis, T., 1978, Essential of Toxicology Third Edition, 13-25, 195-206, Lea \& Febringer, philadelphia

Suckow, M.A., Weisbroth, S.H., \& Franklin, C.L., 2006, The Laboratory Rat, second Ed., 106,133,136, Elsevier Academic Press, USA 
Wijayakusuma, Hembing, M.H., Wilson, L.M., 1994, Patofisiologi Dalimartha, S., Wirian, A.S., Konsep Klinis Proses-Proses 1995, Tanaman Berkhasiat Obat di Indonesia, Jilid IV, 118-119, Penyakit, 427-429, EGC Penerbit Buku Kedokteran, Jakarta 